\title{
O NEGRO NOS MEANDROS DOS DEBATES PARLAMENTARES DA PRIMEIRA REPÚBLICA (1889- 1894)
}

THE BLACK IN THE POLITICAL THOUGHT OF THE FIRST REPUBLIC (1889-1894)

Talita Teixeira 394

\begin{abstract}
Resumo: Com a proclamação da República em 15 de novembro de 1889, iniciou-se um novo período para a história brasileira. Tempo de mudanças políticas, econômicas e sociais. A monarquia fora abandonada, a economia seria pautada na mão de obra assalariada livre e a escravidão transformar-se-ia em coisa do passado. No entanto, ficara para a nascida República uma herança imperial para ser extinta: o preconceito de cor. Missão aparentemente próxima do novo ideal político que exaltava "somos todos iguais!" no hino da Proclamação da República. Assim, nosso objetivo é buscar analisar a imagem de nação almejada após a Proclamação da República, identificando o papel destinado ao negro.
\end{abstract}

Palavras-chave: negro - imagem da nação - República

Abstract: With the proclamation of the Republic on November 15, 1889, began a new period for Brazilian history. Time of political, economic and social changes. The monarchy had been abandoned, the economy would be based in the free hired labor and slavery would become a thing of the past. However, it was left for the new-born Republic an imperial heritage to be extinct: the color prejudice. A mission apparently close to the new political ideal who extolled "we are all equal!" in the anthem of the Republic Day. Thus, our objective is to analyze the image of nation longed after the Proclamation of the Republic, identifying the role for the black.

Key-words: black - the image of nation - Republic

\section{APRESENTAÇÃO}

Há fatos mais extraordinários que a desolação de Babilônia. Há o fato de um preto de Uberaba, que, fugindo agora da casa do antigo senhor, veio a saber que estava livre desde 1888, pela lei da abolição. Faz lembrar o velho adágio inglês: "Esta cabana é pobre, está toda esburacada; aqui entra o vento, entra a chuva, entra a neve, mas não entra o rei". O rei não entrou na casa do exsenhor de Uberaba, nem o presidente da República. O que completa a cena, é que uns oito homens armados foram buscar o João (chama-se João) à casa do engenheiro Tavares, onde achara abrigo. ${ }^{395}$

Passados cinco anos da assinatura da Lei Áurea, Machado de Assis, no periódico Gazeta de Notícias, relatava a descoberta feita por um escravo: a abolição tinha sido ordenada em 1888. O escravo, então, na realidade, já tinha sido libertado e não era mais propriedade de nenhum senhor. Todavia, como nem o rei nem o presidente da República haviam entrado na casa do ex-senhor, este dava continuidade a

\footnotetext{
${ }^{394}$ Mestranda em História pela Universidade Federal do Rio de Janeiro (UFRJ)

${ }^{395}$ Gazeta de Notícias. 01 de janeiro de 1893.
} 
uma instituição que, aparentemente, havia sido abandonada. Desse modo, apesar do Estado ter decretado a abolição, não houve preocupação do governo da época nem do subsequente com os ex-escravos, de maneira que a consolidação da liberdade dos mesmos ficou a cargo do privado.

Por mais que os aniversários da abolição fossem comemorados com louvor e tinham como parte dos festejos oficiais salvas de tiro dadas pelos navios ancorados na Baía de Guanabara, a realidade era nebulosa. O 13 de maio libertara os escravos, mas não rompera com a mentalidade escravocrata. Igualmente, na República, o Estado permaneceu desinteressado pelo destino do liberto.

Assim, procuraremos identificar o papel destinado ao negro no delineamento da imagem da nação após a Proclamação da República. Com esse intuito, serão analisadas as discussões no Senado entre os anos de 1889 e 1894. Não obstante, antes de examinarmos de que maneira a elite política pensava 0 negro e a sua inserção na sociedade, é essencial fazermos uma viagem no tempo. Assim, iniciaremos nosso percurso nos anos finais do Império, momento em que transformações civis, sociais e políticas estavam sendo desenhadas para depois adentrarmos nos meandros do período republicano. A fim de ilustrarmos o cenário da época, alguns periódicos foram examinados.

\section{PELOS MEANDROS DA ABOLIÇÃO}

Maio de 1888. Transcorriam os dias finais da escravidão no Brasil. No dia 8 de maio, através do deputado Rodrigo Silva, o projeto da Lei Áurea era apresentado à Câmara, propondo a abolição sem indenização aos proprietários de escravos. Apesar do posicionamento contrário ao projeto por parte de homens como Andrade Figueira e o deputado Pedro Luiz, a maioria dos deputados, cerca de 85, votaram a favor contra apenas 9 e, assim, o texto foi encaminhado para o Senado no dia 11 de maio de 1888. Para descontentamento de senadores como Paulino de Souza e o Barão de Cotegipe, no dia 13, o projeto virou lei.

Entretanto, ainda que a corrente abolicionista tenha florescido praticamente na última década da escravidão, a extinção da escravidão não aconteceu de uma hora para outra. A instituição da escravidão, por conseguinte, teve que ser superada por meio da ação do Estado mesmo que isso significasse se opor aos interesses sociais e econômicos daqueles que amparavam a monarquia.

Nesse sentido, em finais de 1865, D. Pedro II solicitou a José Antônio Pimenta Bueno, futuro marquês de São Vicente, que elaborasse propostas legislativas para a emancipação de escravos para serem discutidas pelo Legislativo. Um ano depois, o imperador, ao receber uma correspondência de uma 
sociedade abolicionista francesa, reforçou sua posição em prol da emancipação. Nesse momento, 0 projeto de Pimenta Bueno já estava pronto. Em sua apresentação, foram expostos os motivos em prol da emancipação: em primeiro lugar, a instituição da escravidão era condenada no século em questão; em segundo lugar, a escravidão era associada à ideia de barbárie e consequentemente impedia o progresso; por fim, no mundo ocidental, só restava o Brasil como país escravista. ${ }^{396}$

A abolição deveria ser, não obstante, gradual e conduzida pelo Estado, 0 que não abalaria 0 trabalho agrícola, pois a emancipação não seria em grande massa. A maioria dos Conselheiros do Estado, porém, não concordava com a reforma no Legislativo e apostavam na solução demográfica "natural" como morriam mais que nasciam, sem o tráfico intercontinental gradativamente não haveria mais escravos. Por conseguinte, homens como o marquês de Olinda questionavam a comparação com outros países, principalmente, os europeus, já que "os homens públicos da Europa não conheciam a situação dos países nos quais havia escravidão."397

Entretanto, um ponto parecia comum aos conselheiros: era preciso esperar o fim da Guerra do Paraguai, pois "seria necessário espalhar as guarnições do Exército pelas províncias para garantir a segurança pública antes de tomar qualquer medida." ${ }^{398}$ Apenas o visconde de Jequitinhonha discordava do adiamento, pois alegava que como a abolição seria gradual e progressiva, a guerra em andamento não teria porque afetar o debate do projeto. Dessa forma, terminada a guerra, a questão em torno do elemento servil voltaria a ser debatida a pedido do próprio Imperador através da Fala do Trono, pronunciada na abertura da Assembleia Geral de 3 de maio de 1871:

Considerações da maior importância aconselham que a reforma da legislação sobre 0 estado servil não continue a ser uma aspiração nacional indefinida e incerta. É tempo de resolver esta questão, e vossa esclarecida prudência saberá conciliar o respeito à propriedade existente com esse melhoramento social que requerem nossa civilização e até o interesse dos proprietários. ${ }^{399}$

Seria o Visconde do Rio Branco, antigo ministro do gabinete escravocrata, que aderiria à causa em torno da discussão da extinção do elemento servil. ${ }^{400}$ Sob a sua chefia, o gabinete majoritariamente

\footnotetext{
${ }^{396}$ Nas colônias espanholas, Cuba e Porto Rico, o movimento abolicionista crescera em 1865, o que conduziu a aprovação da Lei Moret em 1870 - semelhante a nossa de 1871. Logo, ainda vivíamos sob aspectos de colônia. CHAULHOUB, Sidney. Machado de Assis historiador. SP: Companhia das Letras, 2003, p. 139-141.

${ }^{397}$ Idem, p. 146.

${ }^{398}$ Idem, p. 151.

${ }^{399}$ Falas do Trono. Desde o ano de 1823 até o ano de 1889. Prefácio de Pedro Calmon. Brasília: INL, 1977, p. 397.

${ }^{400}$ José Maria da Silva Paranhos, o Visconde do Rio Branco, apesar de ter defendido a lei, observou, na época, que a matéria era deliberada por desejo do próprio governo, pois não havia como comparar a situação do Brasil com a de outras nações europeias, visto que a escravidão apresentava no país uma importância social maior. No caso dos Estados Unidos, a comparação também não era valida já que o fim da escravidão havia sido instituído pela força. Por conseguinte, não havia no
} 
conservador aprovou a lei do Ventre Livre, defendida, na época, como o meio mais seguro de se obter a extinção gradual da escravidão. O processo do fim da escravidão, portanto, foi lento e seus reflexos permaneceram após a abolição, visto que a sociedade ainda estava marcada por valores hierárquicos ligados ao passado colonial e, nesse sentido, ao passado escravista muito recente.

A abolição, ao decretar o fim da escravidão imediata e sem indenização, além de contribuir para a transformação política do ano seguinte - já que a monarquia perdeu uma de suas bases de apoio ao expropriar os donos de escravos de suas propriedades, o que levou João Maurício Wanderley, barão de Cotegipe, presidente do Conselho de Estado, a declarar que a princesa Isabel, ao libertar uma raça, perdera o trono - gerou uma transformação social no nosso país, pois com a abolição novas modalidades de hierarquia deveriam ser estabelecidas já que uma rede de mecanismos sociais de distinção foi suprimida.

Embora, saibamos, hoje, através dos estudos de historiadores ligados ao tema, que a abolição não contemplou uma quantidade muito grande de escravos, já que a maioria tinha sido alforriada ou pelas leis anteriores ou pelos acordos com os senhores, como ocorreu na maior parte dos casos a partir da década de 70, a lei oficializou que o negro deixava de ser escravo e consequentemente não poderia mais ser visto como uma propriedade privada. ${ }^{401} \mathrm{E}$ a novidade foi festejada com louvor. Na capital, a assinatura da Lei Áurea foi motivo de festa no Largo do Paço, em São Cristóvão, no Boulevard de Vila Isabel. ${ }^{402}$ As celebrações foram tantas que Machado de Assis, posteriormente, lembrando o dia observou:

Houve sol, e grande sol, naquele domingo de 1888, em que o Senado votou a lei, que a regente sancionou, e todos saímos à rua. Sim, também eu saí à rua, eu o mais encolhido dos caramujos, também eu entrei no préstito, em carruagem aberta, se me fazem favor, hóspede de um gordo amigo ausente; todos respiravam felicidade, tudo era delírio. Verdadeiramente, foi o único dia de delírio público que me lembro ter visto. ${ }^{403}$

Brasil um partido que defendesse a abolição. Ao longo de sua defesa pela aprovação da lei, afirmou tratar-se de uma luta por "um meio de emancipação lenta e gradual", capaz de "conciliar" o interesse dos senhores com o interesse público. Para mais informações, consultar: FRANCO, Álvaro da Costa. (org.) Com a palavra, o Visconde do Rio Branco. A politica exterior no Parlamento Imperial. Rio de Janeiro: CHDD/FUNAG, 2005.

${ }^{401}$ Para mais informações, consultar: ALBUQUERQUE, Wlamyra R. de. O jogo da dissimulação - abolição e cidadania negra no Brasil. São Paulo: Companhia das Letras, 2009; CUNHA, Olívia Maria Gomes da; GOMES, Flávio dos Santos (orgs.). Quasecidadão: histórias e antropologias da pós-abolição. Rio de Janeiro: FGV, 2007; GOMES, Heloísa Toller. As Marcas da Escravidão. Rio de Janeiro: EDUERJ, 1994; LARA, Sílvia Hunold. Escravidão, cidadania e história do trabalho no Brasil. Revista projeto História, São Paulo, vol. 16, fevereiro-1998; MATTOS, Hebe Maria, "Racialização e cidadania no Império do Brasil", In: CARVALHO, José Murilo de; BASTOS, Lúcia Maria (orgs.). Repensando o Brasil dos oitocentos. Rio de Janeiro: Civilização Brasileira, 2009; SKIDMORE, Thomas E. Preto no Branco. Raça e nacionalidade no pensamento brasileiro. (19701930) SP: Companhia das Letras, 2012.

${ }^{402}$ A programação dos festejos foi publicada no Diário de Notícias, 15 de maio de 1888.

${ }^{403}$ Gazeta de Notícias. Rio de Janeiro, 14 de maio de 1893. 
Enquanto a questão da abolição, bem como as festas em sua comemoração, estava em voga nos jornais da época, monarquistas e antigos senhores, em busca da manutenção da ordem e da lealdade dos antigos cativos, levantavam a bandeira da liberdade a seu favor. A concepção de uma libertação pacífica, do negro enquanto indivíduo passivo que teria recebido uma verdadeira dádiva concedida pela princesa Isabel, retratada como "a redentora" tornou-se o discurso oficial. A pena de ouro utilizada na assinatura do decreto foi exposta no salão do jornal O Paiz com os seguintes dizeres: "A D. Isabel, a redentora, o povo agradecido." ${ }^{404}$ Os monarquistas, então, buscavam fortalecer a imagem da monarquia e evitar uma crise política, ao passo que os fazendeiros almejavam a permanência dos libertos nas fazendas:

eis os dois lados da mesma moeda que caracterizava uma faceta singular da Abolição brasileira: distante da noção de revolução, nosso processo de libertação escravocrata era representado como pacífico, gradual e, sobretudo, como um "presente dos senhores e do Estado". Aos cativos restava a lealdade e a posição submissa de quem ganha uma dádiva. A liberdade parece representar, nesse sentido, algo bem diferente da noção de mudança e alteração. É antes resignação, acomodação e mudança sem alteração. ${ }^{405}$

Para o Estado estava em jogo sua própria sobrevivência, para os senhores não era só uma questão de perda de mão de obra para a lavoura. Sua posição hierárquica na sociedade, sempre relacionada à propriedade de terras e de escravos, estava sob ameaça. Se, anteriormente, a chance do escravo conquistar a alforria dependia da relação senhor-escravo, a partir de 1888, a alforria não fazia mais parte do jogo de poder que compunha as relações do engenho, o que feria a manutenção de poder dos antigos senhores. Por outro lado, o Estado decretou a abolição, contudo não se ocupou em organizar a mão de obra, tão pouco se preocupou com o caminho que deveriam tomar os ex-escravos, de modo que a libertação ficou a cargo do privado, o que preocupou alguns senhores, visto que o fim da escravidão comprometeu a relação de dominação do senhor para com o escravo e, consequentemente, a relação de trabalho, mas também gerou insegurança por ameaçar a posição hierárquica. Dessa forma, Hebe Mattos e Ana Maria Rios observam que

divididos politicamente entre os que acreditavam que deveriam lutar até o fim por seus direitos de propriedade e os que advogavam que apenas as alforrias em massa antes da abolição incondicional poderiam preservar a ordem e o controle senhorial sobre o processo de libertação, digladiaram-se nos jornais interioranos em cartas dos leitores e matérias assinadas durante os meses que antecederam e que se seguiram ao fim do cativeiro. ${ }^{406}$

\footnotetext{
404 Jornal do Senado, 14 de maio de 1888.

${ }^{405}$ SCHWARCZ, Lilia Moritz. "Dos males da dádiva: sobre as ambiguidades no processo da Abolição brasileira", in: CUNHA, Olívia Maria Gomes da \& GOMES, Flávio dos Santos. Op. Cit., p. 27.
} 
A defesa das alforrias em massa por parte de muitos senhores estava ligada à confiança na gratidão dos libertos e na permanência dos mesmos senão nas fazendas, ao menos na região, por isso 0 sistema de trabalho em geral proposto aos libertos era o da parceria "a eito" - "a continuidade do trabalho coletivo e supervisionado e a divisão da safra com o conjunto dos trabalhadores ao final da colheita". ${ }^{407}$

No entanto, a libertação a cargo do privado permitiu certa continuidade em relação à escravidão. Nas documentações policiais e na imprensa eram divulgadas notícias sobre a permanência obrigatória de escravos em algumas fazendas, visto que muitos senhores recusavam-se a cumprir a lei, o que exigiu providências por parte da polícia local. ${ }^{408}$ Em outros casos, 0 ex-senhor buscava transformar-se no novo patrão, já que se esperava que os ex-escravos permanecessem nas fazendas por gratidão aos seus senhores que colocaram em prática aquilo que fora determinado pela princesa Isabel. Simultaneamente, garantia-se a permanência de mão de obra nas fazendas e a manutenção das hierarquias sociais.

Vale lembrar que mesmo entre os abolicionistas não havia uma unidade de pensamento, nem indivíduos do mesmo grupo político. Liberais, conservadores, monarquistas e republicanos misturavam-se defendendo o projeto abolicionista de diferentes maneiras: com mobilização da camada popular, sem mobilização, reformas sociais para complementar a abolição, ausência de reformas sociais. Dessa forma, por mais que o discurso antiescravista estivesse em pauta, o futuro dos libertos não possuía tanto enfoque.

Todavia, não foram apenas monarquistas e ex-senhores que tentaram utilizar o discurso da liberdade a seu favor. Os republicanos tentavam desvincular a abolição da imagem da princesa e do monarca, defendendo que a lei Áurea fora resultado de um processo de luta e, após a proclamação, 0 governo tentou demonstrar sua simpatia para com o fim da escravidão, de forma que o seu apoio às comemorações do 13 de maio e empenho em colaborar para o bom andamento dos festejos eram destacadas em periódicos, como O Paiz, jornal em circulação no Rio de Janeiro. ${ }^{409}$

Mais uma boa notícia em relação à festa comemorativa do grande dia da pátria. No pavilhão que se está construindo em frente ao quartel-general do Exército, será executado por uma orquestra de 30 professores, secundada pelas bandas de musica do asylo de meninos desvalidos e menores do arsenal de guerra, o grandioso hyno do Dr. Cardoso de Menezes - A Marselhesa dos Escravos, empunhando a batuta o seu talentoso autor. As músicas foram gentilmente

\footnotetext{
${ }^{406}$ MATTOS, Hebe Maria. \& RIOS, Ana Maria. "Para além das senzalas: campesinato, politica e trabalho rural no Rio de Janeiro pós-abolição", in: CUNHA, Olívia Maria Gomes da \& GOMES, Flávio dos Santos. Op. Cit., p. 56.

${ }^{407}$ Idem, p. 57.

${ }^{408}$ Para mais informações, consultar: ALBUQUERQUE, Wlamyra R. de. O jogo da dissimulação - abolição e cidadania negra no Brasil. São Paulo: Companhia das Letras, 2009.

${ }^{409}$ Rui Barbosa, em "Libertos e republicanos" questionou o esforço da monarquia em proteger o trono por meio da mobilização dos libertos. Para mais informações, consultar: CHALHOUB, Sidney. "Medo Branco de Almas Negras: Escravos, Libertos e Republicanos na Cidade do Rio". IN: (Revista Brasileira de História - São Paulo, ANPUH/Marco Zero, vol. 8, no 16, março de 1988 / agosto de 1988.
} 
cedidas pelo governo, em quem tem encontrado a comissão encarregada dos festejos a melhor boa vontade e decidido apoio aos seus esforços. ${ }^{410}$

Quando houve a decretação da abolição, devido às alforrias, a quantidade de "livres de cor" era superior à quantidade de escravos, porém a acepção da liberdade para esses indivíduos não deve ser negligenciado, pois o fato de serem livres não lhes garantiam direitos políticos, além da sociedade permanecer escravista. Ademais, em alguns casos, a abolição gerou outras reinterpretações para liberdade, visto que em regiões como Amazonas e Ceará a emancipação dos escravos tinha sido decretada no início da década de 1880. Com a abolição, por conseguinte, o estatuto de escravo possivelmente seria modificado para o de cidadão, assim como as relações de trabalho. Todavia, como observam os autores Olívia da Cunha e Flávio Gomes,

em muitos casos, a liberdade não significou o avesso da escravidão. Em outros, a sujeição, a subordinação e a desumanização, que davam inteligibilidade à experiência do cativeiro, foram desqualificadas num contexto posterior ao término formal da escravidão, no qual as relações de trabalho, de hierarquia e de poder abrigaram identidades sociais se não idênticas, similares àquelas que determinada historiografia qualificou como exclusivas ou características das relações senhor-escravo. ${ }^{411}$

Diante da falência do modelo de diferenciação social anterior - senhor/escravo - os interessados nos mecanismos de exclusão buscaram redefinir as hierarquias pautadas em critérios sociais a fim de garantir a manutenção do status quo. Argumentos raciais, nesse sentido, passaram a ser utilizados politicamente e historicamente para garantir o estabelecimento das diferenças sociais e o distanciamento dos libertos do poder político e econômico, por isso

entender alguns dos significados conferidos às ideias de "liberdade" e às formas de inscrição social baseadas em critérios como cor e raça, naqueles contextos, nos ajuda a interpretar os limites tênues de atos que balizaram simbólica e formalmente - mas não transformaram social e politicamente - as formas de acesso à cidadania e à igualdade existentes no Brasil durante a escravidão. ${ }^{412}$

\footnotetext{
410 "13 de maio", in: O Paiz. Rio de Janeiro, 8 de maio de 1890.

${ }^{411}$ CUNHA, Olívia Maria Gomes da. \& GOMES, Flávio dos Santos. (orgs.) "Introdução", in: Op. Cit., p. 11.

${ }^{412}$ Idem, p. 11.
} 
Na década de 1870, os ideários científicos europeus entraram no Brasil. ${ }^{413}$ Nesta época, D. Pedro II, que elegia a ciência como referencial, almejava aproximar a imagem do Brasil aos modelos europeus, ao mesmo tempo em que desejava se diferenciar das repúblicas latino-americanas. Assim, os modelos evolucionistas e o social darwinismo - por terem como objeto central de análise 0 estudo das raças e a contribuição de cada uma - foram os modelos de ciência que chegaram ao país com mais força, levando os "homens de sciencia", congregados nos institutos de pesquisa, a discutir os obstáculos bem como as perspectivas que se apresentavam ao país. Entretanto, por mais que tais teorias, principalmente 0 darwinismo social, tenham sido bem aceitas no Brasil, os intelectuais brasileiros buscaram a melhor forma de aplicá-las à situação nacional, visto que deveriam ser compatíveis com a realidade brasileira, marcada pela multirracialidade. ${ }^{414}$

\begin{abstract}
O que interessava não era recordar o debate original, restituir a lógica primeira dessas teorias, ou o contexto de sua produção, mas, antes, adaptar o que "combinava" - da justificativa de uma espécie de hierarquia natural à comprovação da inferioridade de largos setores da população - e descartar o que de alguma maneira soava estranho, principalmente quando essas mesmas teorias tomavam como tema os "infortúnios da miscigenação". (...) $O$ ato de traduzir não se limita, portanto, a simplesmente revelar um conhecimento. A tradução implica seleção previa de textos e escolha de certos autores em detrimento de outros. No caso, o pensamento racial europeu adotado no Brasil não parece fruto da sorte. Introduzido de forma crítica e seletiva, transforma-se em instrumento conservador e mesmo autoritário na definição de uma identidade nacional e no respaldo a hierarquias sociais já bastante cristalizadas. ${ }^{415}$
\end{abstract}

Gradativamente, o discurso racial transformar-se-ia num variante para a cidadania, dessa maneira, "a igualdade conseguida mediante as conquistas políticas era negada em nome da natureza." ${ }^{416} \mathrm{~A}$ abolição

\footnotetext{
${ }^{413}$ Segundo Lilia Schwarcz, foi no século XVIII que a existência de diferenças entre os homens começou a ser pensada por indivíduos como Buffon, naturalista francês, e pelo jurista Cornelius de Pauw e, no início do século XIX, o termo raça foi introduzido por Georges Cuvier. Ainda no século XIX, duas correntes passaram a pensar a origem do homem: os monogenistas e os poligenistas. A partir dessas ideias, consoante a autora, as teorias raciais passaram a ser pensadas por diferentes escolas que roubaram a cena e se popularizaram nos Estados Unidos e na Europa ainda nas décadas de 1840. Para a escola etnológica-biológica, pautada na teoria da poligenia, as raças humanas sempre apresentaram diferenças entre si - o tamanho do crânio seria um exemplo - e essas diferenças, que eram vitais na identificação das raças inferiores e das raças superiores, tinham sido resultado de espécies criadas separadamente. A corrente da escola histórica, representada por homens como Gobineau, defendia que as raças humanas eram bem diferenciadas e que a superioridade ou inferioridade de uma determinada raça poderia ser verificada através de evidências históricas. Por fim, o darwinismo social, apesar de se diferenciar da escola etnologia-biológica, por acreditar que o processo evolutivo começava a partir de uma única espécie, aproximava-se da mesma ao defender que num processo evolutivo, as raças superiores eram o resultado de uma melhor adaptação e isso explicaria o encolhimento ou desaparecimento das raças inferiores com o passar do tempo. SCHWARCZ, Lilia Moritz. O espetáculo das raças. Cientistas, instituições e questão racial no Brasil (1870-1930). São Paulo: Companhia das Letras, 2011.

${ }^{414}$ Comparando o Brasil com os Estados Unidos, Thomas Skidmore observa que diferentemente dos EUA, caracterizados por ser birracial, o Brasil era multirracial devido a uma série de fatores: a grande quantidade de negros e mulatos libertos antes da abolição; a mestiçagem e a escravidão ter sido em âmbito nacional, não regional. Para mais informações, ver: SKIDMORE, Thomas E. "As realidades raciais e o pensamento racial depois da abolição.", in: Op. Cit., p. 80-127.

${ }^{415}$ SCHWARCZ, Lilia Moritz. O espetáculo das raças. Op. Cit., p. 41-42.

${ }^{416}$ Idem, p. 241.
} 
decretou a liberdade, mas não modificou o estatuto social dos cativos, tampouco garantiu sua inscrição social de modo a torná-los cidadãos plenos. Assim, os "ex-escravos e "livres de cor" tornaram-se cidadãos em estado contingente: quase-cidadãos." ${ }^{417}$ Não obstante, pouco mais de um ano depois, a República seria proclamada. Ficaria para o novo modelo político a missão de implementar as alterações que 013 de maio pôs em funcionamento.

\section{REPÚBLICA: (IM)POSSIBILIDADE DE MUDANÇA}

Novembro de 1889. O modelo monárquico e hereditário no Brasil chegava ao final diante da proclamação da República, realizada pelo marechal Deodoro da Fonseca, na atual Praça da República, localizada na cidade do Rio de Janeiro. No espaço de pouco mais de um ano, duas mudanças fundamentais - a abolição e a proclamação da República - para a história do país. Aparentemente, ambas resultariam no estabelecimento da igualdade civil de todos os brasileiros, firmada no artigo 72 da nova Constituição: "todos são iguais perante a lei". ${ }^{418}$ Todavia, a igualdade ficaria apenas no âmbito jurídico, visto que a res publica não se traduziu em "coisa pública".

O governo provisório e os seus ministros tiveram que buscar resolver as mesmas questões que anteriormente afligiram o Império: a indenização pela abolição, a autonomia das províncias e a anarquia militar. Os fazendeiros continuavam insatisfeitos, as províncias permaneciam questionando o centralismo econômico-administrativo e grupos militares mantinham-se indisciplinados. ${ }^{419}$ Logo, além de governarem uma nação heterogênea, com questões a serem resolvidas, ainda tinham que consolidar o novo modelo político recentemente instaurado.

Por outro lado, havia também o objetivo de superar o passado escravista, apesar de que tanto a elite econômica quanto 0 Estado não se preocuparam em proporcionar condições favoráveis na transição entre a condição de cativo presente no mundo servil para a condição de cidadão pleno de direitos, visto que as heranças ideológicas e as marcas simbólicas da escravidão não foram alteradas. Embora não

\footnotetext{
${ }^{417}$ CUNHA, Olívia Maria Gomes da \& GOMES, Flávio dos Santos. (orgs.) Op. Cit., p. 13.

${ }^{418}$ Disponível em http://www.planalto.gov.br/ccivil_03/constituicao/constituica091.htm

${ }^{419}$ Reflexo da Guerra do Paraguai que fez surgir uma nova geração de altos oficiais, aumentou os laços de solidariedade entre os componentes, tornando o Exército mais corporativista e gerou um sentimento de barganha, pois como tinham ganhado a guerra, começaram a protestar por acreditar que o Império lhe devia algo. Paralelamente, as aulas de positivismo e teorias políticas foram politizando oficiais e cadetes. Para mais informações, consultar: SCHWARCZ, Lilia Moritz. População e sociedade, in: SCHWARCZ, Lilia Moritz. (org.) A Abertura para o mundo. 1889-1930. Volume 3 da Coleção: História do Brasil nação: 1808-2010. RJ: Editora Objetiva, 2012, pp. 35-83.
} 
estivesse preocupado com a situação dos ex-escravos, mas com a dos lavradores, o senador Antônio Bernardino Monteiro de Barros, em sessão de 2 de agosto de 1892, abordou um problema do pós abolição.

os abolicionistas, conseguido seu fim de arrancar o escravo aos proprietários, não se importaram com ele, e os proprietários, empobrecidos, nada mais puderam fazer do que lutar com as dificuldades que os assoberbam, de falta de crédito e braços úteis. ${ }^{420}$

Neste sentido, se avaliarmos os anos compreendidos entre o Império e a República, "do ponto de vista do progresso da cidadania, a única alteração importante que houve nesse período foi a abolição da escravidão, em 1888." ${ }^{421}$ Em mensagem dirigida ao Congresso Nacional pelo chefe do governo provisório, Manoel Deodoro da Fonseca, em 15 de novembro de 1890, saldava o fim da instituição servil.

felizmente para a causa democrática havia desaparecido completamente a nefanda instituição do trabalho servil que trazia o senhor e 0 escravo acorrentados no mesmo grilhão, ao qual se prendiam, por mil dependências diversas, todas as manifestações da vida econômica nacional. ${ }^{422}$

No entanto, a escravidão, por mais que estivesse extinta, deixara resquícios que não seriam facilmente apagados. Para deputados como Inocêncio Serzedello Correia, representante do Pará, 0 Congresso teria a missão de reconstruir uma obra inteira, visto que a escravidão havia impedido que a educação política e moral operasse na Nação. ${ }^{423}$ Neste mesmo sentido, o deputado José Joaquim Seabra, representante da Bahia, em sessão presidida por Prudente de Morais, em 20 de dezembro de 1890, apresentou para discussão no Congresso uma moção proposta do Governo Provisório, por meio da qual 0 mesmo desejava extinguir os vestígios da escravidão presentes nos arquivos nacionais a fim de acabar, nas palavras do deputado, "de uma vez para sempre com aquilo que era a nossa vergonha, a página negra da história do Brasil." 424

Posicionando-se contra, por entender que tal questão envolvia interesses históricos, o deputado Francisco Coelho Duarte Badaró, representante de Minas Gerais, alertou:

Sr. Presidente, não quero que ninguém entenda que, ao levantar para pronunciar-me contra esta moção, eu pretenda condenar a obra meritória dos abolicionistas. O que faço é protestar contra 0 ato de cremaçãa de todo 0 arquivo da escravidão no Brasil, porque envolve interesse históricos. Nós, em vez de procurar destruir o que é uma obra de verdadeiros iconoclastas, devíamos ter a

\footnotetext{
${ }^{420}$ Anais do Senado Federal. Volume III, livro 4, 1892, p.86.

${ }^{421}$ CARVALHO, José Murilo de. Cidadania no Brasil. O longo caminho. Rio de Janeiro: Civilização Brasileira, 2013 , p. 17.

${ }^{422}$ Anais do Congresso Constituinte da República. Volume I, 1890, p. 2.

${ }^{423}$ Idem, p. 716.

424 Idem, p.787.
} 
nossa Torre do Tombo, um edifício destinado a recolher os papeis de todos os arquivos do pais. ${ }^{.425}$

Em concordância, o deputado Antonio Affonso Lamounier Godofredo, representante de Minas Gerais, ressaltou:

$$
\text { a vergonha nunca há de deixar de existir; não é a cremação que a fará desaparecer. }{ }^{426}
$$

Por fim, Badaró reafirmou sua posição, concluindo:

além disso, não se pode fazer apagar os vestígios da escravidão porque para atesta-la, ai está a debilidade da nossa raça. ${ }^{427}$

Na realidade, a destruição dos documentos tinha sido proposta por Joaquim Nabuco na Câmara dos Deputados ainda em julho de 1888. Em 1890, seria o ministro da Fazenda, Rui Barbosa, quem iria ordenar a cremação dos arquivos referentes à escravidão, iniciada no ano seguinte por meio de circular expedida pelo Ministro da Fazenda sob o n. 29 e com data de 13 de maio de 1891. Aparentemente, a causa para a queima desses documentos seria exclusivamente econômica, visto que a medida visava proteger os cofres públicos de um contra-ataque dos antigos senhores de escravos, empenhados na indenização por perdas causadas pela Lei Áurea. ${ }^{428}$

Todavia, independentemente da real motivação do ministro do governo provisório, percebemos, através da discussão no Senado que não eram apenas razões econômicas que moviam o apoio à cremação. Da mesma forma, o posicionamento contrário, por parte de Badaró e de Lamonier Godofredo, não exclui a mentalidade marcada por aspectos raciais. Tanto Inocêncio Serzedello Correia e Seabra - os deputados que se posicionam a favor da cremação - quanto Badaró e Lamonier Godofredo - os deputados que se posicionam contra a cremação - possuem um discurso marcado pela ideologia de uma sociedade escravista.

Ao longo da discussão para delimitação da nova Constituição, o voto se revelou como um dos principais aspectos mantenedor da hierarquia social já existente. Pelo art. 70, seriam considerados eleitores os cidadãos maiores de 21 anos, contudo, estariam excluídos os mendigos, os analfabetos, os

\footnotetext{
${ }^{425}$ Idem, p.788.

${ }^{426}$ Idem, p.788

${ }^{427}$ Idem, p.788

${ }^{428}$ Para estas informações, consultar: LACOMBE, Américo Jacobina; SILVA; Eduardo Silva e BARBOSA, Francisco de Assis. Rui Barbosa e a Queima dos Arquivos. Brasília: Ministério da Justiça; Rio de Janeiro: Fundação Casa de Rui Barbosa, 1988, p. 11-26; FREIRE, Gilberto. Casa-Grande \& Senzala. Formação da Família Brasileira sob o Regime da Economia Patriarcal. São Paulo: Ed. Global, 2006, p. 383-384.
} 
praças de pret e os religiosos sujeitos a votos de obediência. ${ }^{429}$ Se comparado com a Constituição de 1824 , houve um retrocesso.

A primeira Constituição do país entrou em vigor dois anos após a independência, determinando que a forma de governo fosse uma monarquia hereditária, constitucional e representativa, logo, a Constituição outorgada de 1824, deu início ao voto dos cidadãos e a separação dos poderes - Executivo, Legislativo, dividido em Senado e Câmara, Judiciário e Moderador. A Câmara dos Deputados seria eletiva e temporária com mandato de quatro anos, enquanto o Senado seria organizado por meio de eleição provincial - a quantidade de senadores de cada província deveria ser a metade do número dos seus deputados; os senadores seriam eleitos em listas tríplices, das quais o Imperador escolheria o terço da totalidade - e seus membros seriam vitalícios. As eleições eram indiretas, de modo que primeiramente os cidadãos ativos em Assembleias Paroquiais elegeriam os eleitores de província e estes, por sua vez, elegeriam os representantes da nação. O poder Moderador possibilitava, dentre outras prerrogativas, a nomeação de ministros, diferenciando o modelo brasileiro do modelo inglês. ${ }^{430}$

Em relação aos direitos políticos, estavam qualificados para o voto homens maiores de 25 anos que tivessem uma renda líquida anual de cem mil reis, excetuando os que tivessem idade de 21 anos e já fossem casados - estes já poderiam votar - oficiais militares, bacharéis formados e clérigos. Todavia, somente poderiam ser eleitores de província quem tivesse uma renda líquida anual de duzentos mil reis, quem não fosse liberto ou quem não fosse um criminoso sentenciado em querela ou devassa. Ademais, todos os eleitores deveriam professar a religião do Estado. De acordo com José Murilo de Carvalho,

a limitação da renda era de pouca importância. A maioria da população trabalhadora ganhava mais de 100 mil reis por ano. (...) A lei brasileira permitia ainda que os analfabetos votassem. Talvez nenhum país europeu da época tivesse legislação tão liberal. (...) Em tese, ela permitia que quase toda a população adulta masculina participasse da formação do governo. (...) De acordo com o censo de 1872, 13\% da população total, excluídos os escravos, votavam. ${ }^{431}$

No entanto, em 1881, diante da reforma eleitoral| ${ }^{432}$, cujo projeto fora formulado por Rui Barbosa e

\footnotetext{
${ }^{429}$ Disponível em http://www.planalto.gov.br/ccivil_03/constituicao/constituica091.htm

${ }^{430}$ Segundo José Murilo de Carvalho, a monarquia parlamentar brasileira "poderia ser chamado de monarquia presidencial, de vez que no presidencialismo republicano a nomeação de ministros também independe da aprovação do Legislativo", in: CARVALHO, José Murilo de. Op. Cit., p. 30.

${ }^{431}$ Idem, p. 29-31.

${ }^{432} \mathrm{Em} 1879$, a Câmara dos Deputados aprovou o projeto de reforma eleitoral por meio do qual se propunha a reforma por meio da reforma da Constituição de 1824. Todavia, o projeto não foi aprovado pelo Senado. Dessa forma, a reforma eleitoral de 1881, conhecida também como Lei Saraiva, foi realizada por lei ordinária e estabelecida pelo Decreto de número 3.029, de 9 de janeiro de 1881. Para mais informações, consultar: BRASIL. Decreto $n^{0} 8213$, de 13 de agosto de 1881. Regula a execução da Lei $n^{0} 3029$ de 9 de janeiro do corrente ano que reformou a legislação eleitoral. Coleção das Leis do Império do Brasil. Rio de Janeiro, v. 2, p. 854-923. 1881.
} 
submetido ao imperador por José Antônio Saraiva, esse quadro mudaria. Aprovada em 9 de janeiro, por uma bancada liberal, a Lei Saraiva determinou o voto direto, acabando com a eleição em dois graus e a distinção entre "votantes" e "eleitores"; voto facultativo e a renda mínima de 200 mil reis que deveria ser comprovada consoante a lei. Para José Murilo de Carvalho, o aumento da renda não representou exclusão significativa da participação eleitoral. Contudo, como a forma de comprovar a renda era muito rígida, "muitas pessoas com renda suficiente deixavam de votar por não conseguirem provar seus rendimentos ou por não estarem dispostas a ter o trabalho de prová-los." ${ }^{433}$

Se a Constituição de 1824 não falava nada sobre os analfabetos, 0 artigo 8 da reforma eleitoral determinou que a partir de 1882, em todos os anos subsequentes, deveria ocorrer uma revisão do alistamento geral dos eleitores para eliminação ou inclusão de cidadãos no alistamento eleitoral sob a exigência de comprovação de ter adquirido as qualidades de eleitor em conformidade com a lei.

$\S 1^{0} \mathrm{~A}$ prova de haver 0 cidadão attingido a idade legal será feita por meio da competente certidão; e a de saber ler e escrever pela lettra e assignatura do cidadão que requerer a sua inclusão no alistamento, uma vez que a lettra e firma estejam reconhecidos por tabellião no requerimento que para este fim dirigir. ${ }^{434}$

Ainda na mesma lei, 0 artigo 26 reafirmou a exclusão dos analfabetos.

Art. 26. 0 cidadão que requerer sua inclusão no alistamento deverá provar, além da renda legal pelo modo estabelecido no Capitulo $2^{\circ}$ deste Regulamento: (...) $\S 2^{\circ}$ Saber ler e escrever. Será provada esta habilitação pela lettra e assignatura do cidadão que requerer a sua inclusão no alistamento, uma vez que a lettra e a firma estejam reconhecidas por tabellião no requerimento que para este fim dirigir. ${ }^{435}$

Ao longo das discussões da reforma eleitoral de 1881, políticos como o senador Cristiano Ottoni, 0 Conde de Baependy, o deputado Aristides César Spínola Zama e o senador Domingos José Nogueira Jaguaribe defenderam a exclusão dos analfabetos. O deputado Aristides César Spínola Zama posicionouse contra o voto dos analfabetos baseado no argumento da periculosidade.

Senhores, este projeto tem um defeito e é querer fazer um eleitorado permanente e vitalício sobre uma base de sua natureza móvel, qual é a renda. (...) O que deve constituir base para um eleitorado vitalício e permanente é, não pode ser deixar de ser, a capacidade intelectual, a educação necessária para apreciar a marcha dos negócios públicos do país. É esta a única base que não se perde porque, quanto à fortuna, nós estamos vendo todos os dias, por exemplo,

\footnotetext{
${ }^{433}$ Idem, p. 39.

${ }^{434}$ Disponível em http://www.tse.jus.br/eleitor/glossario/termos/lei-saraiva

435 Idem.
} 
milionários tornarem-se pobres no dia seguinte. (...) Digam o que quiserem: o projeto exige para 0 exercício do direito de voto a condição de saber ler e escrever; quem não sabe ler e escrever pode ser qualificado, mas não pode votar. ${ }^{436}$

A reforma de 1881 diminuiu consideravelmente as estatísticas eleitorais, de modo que o percentual de votantes caiu de 13\%, em 1872, para 0,8\% da população total. ${ }^{437}$ Todavia, com a proclamação da República 8 anos depois e a promulgação da nova Constituição, em 24 de fevereiro de 1891, acreditava-se que tais estatísticas iriam voltar a subir. Por ser inspirada na Revolução Francesa e na Constituição dos Estados Unidos e por ter acabado com os privilégios monárquicos, a primeira Constituição republicana parecia que iria por fim aos aspectos excludentes do Império, mas apesar de ter acabado com o voto censitário, manteve a exclusão do voto aos praças, mendigos, membros de ordens religiosas, mulheres e analfabetos e pareceu seguir pelo mesmo percurso da reforma eleitoral de 1881.

Havia dentre os políticos da época, indivíduos que se posicionaram contra a exclusão dos analfabetos. Era o caso do representante do estado do Pará, Lauro Sodré, que apontava como uma das obras da República a depuração moral e a regeneração dos nossos costumes. Para o deputado, o século XIX era um século em que os povos civilizados estavam vivenciando a emergência de aspirações da grande massa e por isso era contra a exclusão da massa brasileira do sufrágio. Ademais, a restrição ao analfabeto excluía do direito ao voto homens que trabalhavam para o progresso do país e representava uma contradição aos princípios que moviam a carta constitucional.

Sou dos que entendem que o voto é uma função social. (...) saber ler e escrever é possuir um instrumento de instrução, apenas e vós havereis de descobrir entre os chamados iletrados quem possuísse maior soma de luzes, mais larga dose de bom senso. Estamos em uma fase social que se acentua pela elevação do proletariado. Se lançarmos os olhos para os povos civilizados, se percorrermos com a vista as nações policiadas, havemos de ver que em todas elas se vai levantando a grande massa. ${ }^{438}$

Contra o pronunciamento de Lauro Sodré, o deputado José Candido de Lacerda Coutinho, representante do estado de Santa Catarina, observou que o direito eleitoral, em nenhum outro país, foi concedido aos analfabetos, visto que não possuem capacidade para votar. Para Lacerda Coutinho,

o direito eleitoral não é um direito natural, é função politica; não é direito como o da liberdade e outros. O homem nasce livre, mas não nasce eleitor. Não vota como homem, mas sim como

\footnotetext{
${ }^{436}$ Anais da Câmara dos Deputados. Sessão de 23 de junho de 1880, p. 427-428.

${ }^{437}$ CARVALHO, José Murilo de. Op. Cit., p. 39.

${ }^{438}$ Anais do Congresso Constituinte da República. Sessão de 13 de janeiro de 1891. Volume II, 1890, p. 476.
} 
cidadão. Para exercer esta função requer-se a capacidade necessária e esta não a possue 0 analfabeto. ${ }^{439}$

O deputado lembrou ainda que os analfabetos no Brasil, que constituíam a massa da população, provinham também da lei Áurea, de modo que grande parte dos analfabetos do país era oriunda da escravidão, o que poderia ajudar no aumento da passividade do eleitorado brasileiro, além de não estimular a superação da ignorância. Em concordância, o deputado José da Costa Machado e Souza, representante do estado de Minas Gerais, ao apresentar seu apoio ao voto feminino, expôs simultaneamente seu posicionamento sobre o voto de ex-escravos.

Como podeis, senhores, conceber que o ex-escravo, que não se educou, vote, e a sua exsenhora, que paga impostos, que tem interesse nos negócios públicos, não vote? (...) e, coerente com os princípios da escola republicana, a que pertenço, faço votos para que o Congresso, bem inspirado, dê uma pátria à nossa mae, à nossa esposa, à nossa filha e à nossa irmã; os escravos, as manadas de irracionais, não tem pátria: não há pátria sem liberdade, não há liberdade sem direitos. ${ }^{440}$

Em contrapartida, o deputado Demetrio Nunes Ribeiro, ex-ministro da Agricultura, Indústria e Comércio, representante do Rio Grande do Sul, pediu a palavra para enviar à Mesa uma representação do Apostolado Positivista do Brasil, propondo modificações no projeto de Constituição apresentado pelo Governo. Dentre as sugestões para modificação, estava a proibição do voto para analfabeto.

art. 70, suprimam-se os ns 1 e 2. Estas exclusões, além de odiosas, são ilusórias, porque nem os mendigos são os únicos cidadãos dependentes, e, nem os analfabetos são os únicos cidadãos incompetentes para exercerem a apreciação politica que a função eleitoral supõe. Pode até acontecer que haja mendigos e muitos analfabetos superiores em critério moral e social a muitos capitalistas e letrados. ${ }^{441}$

Em concordância com o deputado Demetrio Ribeiro, os senadores Ramiro Fortes de Barcellos, Julio Anacleto Falcão da Frota e José Gomes Pinheiro Machado e os deputados Joaquim Francisco de Abreu, Alexandre Cassiano do Nascimento, Alcides de Mendonça Lima, Fernando Abbott, Julio Prates de Castilhos, Homero Baptista, Antonio Adolpho da Fontoura Menna Barreto, Joaquim Pereira da Costa e Thomaz Thompson Flores - todos representantes do estado do Rio Grande do Sul - em sessão de 15 de janeiro de 1891, declararam ter votado "pelas emendas que mandam suprimir os ns. 2 e 4 do primeiro

\footnotetext{
${ }^{439}$ Anais do Congresso Constituinte da República. Sessão de 14 de janeiro de 1891. Volume II, 1890, p. 542.

${ }^{440}$ Anais do Congresso Constituinte da República. Sessão de 27 de janeiro de 1891. Volume III, 1890, p. 218-225.

${ }^{441}$ Anais do Congresso Constituinte da República. Sessão de 13 de dezembro de 1890. Volume I, 1890, p. 477.
} 
paragrafo do art. 70, não impedindo que possam ser eleitores os analfabetos e religiosos." ${ }^{442} \mathrm{O}$ mesmo havia feito o deputado Francisco de Paula Amaral, representante do estado de Minas Gerais, alguns dias antes, em sessão de 11 de fevereiro de 1891, quando declarou ter votado

para que fosse suprimido 0 n.4 do paragrafo 1 do art. 69 do projeto de Constituição, porque entendo que todos os religiosos devem exercer o direito de voto, e mesmo os cidadãos mendigos e analfabetos; pelo que também votei pela supressão dos ns. 1 e 2 dos referidos parágrafos do art.69. ${ }^{43}$

Segundo o deputado José Luiz de Almeida Nogueira, representante do estado de São Paulo,

a melhor Constituição nem sempre é aquela que consigna os mais adiantados princípios do Direito Público universal, mas aquela que alcança o predicado de ser a mais adaptada às peculiaridades do pais o qual legisla. Entretanto, a nossa sociedade, livre de preconceitos, é um terreno amainado para receber em seu seio as mais preciosas sementes da civilização moderna. $^{444}$

No entanto, os discursos apresentados demonstram que a realidade era outra da apresentada pelo deputado Almeida Nogueira. A Constituição de 1891, ao excluir a maior parte da população do sufrágio, não só demonstrou que não estava adaptada às peculiaridades do país, como representou um retrocesso se comparada com a Constituição de 1824. Embora não houvesse na lei nenhum artigo que explicitasse a exclusão dos ex-escravos do direito ao voto, por intermédio de argumentos expostos, como o do deputado Costa Machado e Souza, percebemos que a exclusão dos analfabetos simbolicamente representava também uma forma de excluir os ex-escravos do processo eleitoral. Livres das amarras da escravidão, os libertos pela lei de 1888 não estavam livres da mentalidade ainda marcada pela escravidão, o que os impedia de alcançar a cidadania plena.

Através da cidadania, o indivíduo estaria no gozo dos seus direitos e desempenharia simultaneamente deveres para com o Estado. O conceito de cidadania, no sentido moderno, deriva da Revolução Francesa e, consequentemente, relaciona-se à ideia de cidadania romana, por meio da qual se pressupunha o direito do cidadão de participar das decisões políticas. ${ }^{445}$ Todavia, o conceito foi ampliado, conforme esclarece José Murilo de Carvalho e passou a englobar o exercício dos direitos políticos, civis e sociais. Caso o indivíduo fosse detentor dos três direitos, seria considerado um cidadão pleno. Se

\footnotetext{
${ }^{442}$ Anais do Congresso Constituinte da República. Sessão de 15 de janeiro de 1891. Volume II, 1890 p. 17.

${ }^{443}$ Anais do Congresso Constituinte da República. Sessão de 11 de fevereiro de 1891. Volume III, 1890, p. 572.

${ }^{444}$ Anais do Congresso Constituinte da República. Sessão de 2 de janeiro de 1891. Volume II, 1890, p. P. 39.

${ }^{445}$ Para mais informações a este respeito, consultar: PINSKY, Jaime. \& PINSKY, Carla Bassanezi. (orgs.) História da cidadania. São Paulo: Ed. Contexto, 2013.
} 
possuísse apenas alguns, seria um cidadão incompleto ou um "quase-cidadão" ${ }^{446}$ e se não possuísse nenhum dos direitos, não seria um cidadão. Em relação a cada direito, 0 autor explica que

Direitos civis são os direitos fundamentais à vida, à liberdade, à propriedade, à igualdade perante a lei. (...) É possível haver direitos civis sem direitos políticos. Estes se referem à participação do cidadão no governo da sociedade. Seu exercício é limitado a parcela da população e consiste na capacidade de fazer demonstrações politicas, de organizar partidos, de votar, de ser votado. Em geral, quando se fala de direitos políticos, é do direito do voto que se está falando. Se pode haver direitos civis sem direitos políticos, o contrário não é viável. Sem os direitos civis, sobretudo a liberdade de opinião e organização, os direitos políticos, sobretudo o voto, podem existir formalmente mas ficam esvaziados de conteúdo e servem antes para justificar governos do que para representar cidadãos. (...) Finalmente, há os direitos sociais. Se os direitos civis garantem a vida em sociedade, se os direitos políticos garantem a participação no governo da sociedade, os direitos sociais garantem a participação na riqueza coletiva. (...) Em tese eles podem existir sem os direitos civis e certamente sem os direitos políticos. (...) Os direitos sociais permitem às sociedades politicamente organizadas reduzir os excessos de desigualdade produzidos pelo capitalismo e garantir um mínimo de bem-estar para todos. A ideia central em que se baseiam é a da justiça social. ${ }^{447}$

A questão racial, portanto, manteve-se como argumento para o estabelecimento e legitimação de diferenças sociais mesmo no pós-abolição e no pós-proclamação, de modo que era preservado aspecto reafirmador da rígida hierarquia social. O discurso marcado pela rigidez da concepção hierárquica da sociedade pode ser examinado em outras discussões no Senado.

Ainda em 1888, a Câmara dos Deputados discutiu o Projeto de Repressão à Ociosidade, a fim de legitimar a repressão e reeducação dos vadios, como observado no capítulo XIII do Código Penal de 1890. A preocupação principal era a de definir novos valores para nortear o convívio social e defender a ordem pública, por isso, por exemplo, a escolha pela utilização de termos a fim de classificar comportamentos sociais indesejados. Sete anos depois, por conseguinte, foi criada a Guarda Cívica, com poder de prisão, com a finalidade de policiar, principalmente, as festas populares e as praças públicas.

Em sessão de 16 de janeiro de 1891, o deputado Alexandre José Barbosa Lima, representante do estado do Ceará, defendeu uma emenda contra a promulgação de leis que buscassem impedir a vadiação e a mendicidade, posicionando-se contrário a determinações implementadas pelo Código Penal de 1890. Para o deputado, tais questões possuíam caráter puramente moral e o Estado não deveria se inquietar com aspectos dessa natureza.

\footnotetext{
${ }^{446}$ O termo é de Olívia da Cunha e Flávio Gomes. CUNHA, Olívia Maria Gomes da. \& GOMES, Flávio dos Santos. Op. Cit.

${ }^{447}$ CARVALHO, José Murilo de. Cidadania no Brasil. O longo caminho. Op.Cit., p.8.
} 
Ora, o Estado legisla sobre crimes e delitos, e não sobre pecados apenas. (...) este Código, que contem disposições como esta (lê): art. 399. Deixar de exercitar profissão, oficio ou qualquer mister em que ganhe a vida, não possuindo meios de subsistência e domicilio certo em que habite, etc. Pena - de prisão celular por 15 a 30 dias. Ora, meus senhores, vamos sublinhar não possuindo meios de subsistência, não exercitar profissão. Pois isto é cousa que dependa da vontade de ninguém? Quantos pais de família encontramos todos os dias amargurados para alcançar o pão para os seus e não o conseguindo muitas vezes senão pela esmola? Pois, um cidadão que encontra dificuldades, que não encontra quem the estenda a mão, que 0 arrime, quem 0 introduza na secretaria dos ministros, quem the arranje privilégios, concessões, porque comete 0 grande crime de não ter meios de subsistência, há de ser por isso punido? ${ }^{448}$

Todavia, a problemática em torno da mendicidade e vadiagem permaneceu como pauta de discussão. Em sessão de 8 de outubro de 1892, o primeiro secretário da Câmara dos Deputados enviou para o Congresso Nacional uma proposição de n. 91, por meio da qual seria estabelecida uma colônia no território nacional para corrigir os "vadios".

O Congresso Nacional decreta: art.1. o governo fundará uma colônia correcional no próprio nacional - Fazenda da Boa Vista - existente na Parayba do Sul ou onde melhor the parecer, devendo aproveitar, além daquela fazenda, as colônias militares atuais que a isso se prestarem, para correção, pelo trabalho, dos vadios, vagabundos e capoeiras que forem encontrados e como tais processados na Capital Federal. ${ }^{449}$

Segundo o senador Ubaldino do Amaral Fontoura, representante do estado do Paraná, em sessão de 8 de maio de 1893, o projeto tinha o intuito de expurgar os vadios, capoeiras e demais viciosos da Capital Federal. Eram qualificados como vadios e capoeiras "os indivíduos de qualquer sexo e qualquer idade que, não estando sujeito ao poder paterno ou sob a direção de tutores ou curadores, sem meios de subsistência, por fortuna própria, arte, oficio, ocupação legal e honesta em que ganhem a vida, vagarem pela cidade na ociosidade." ${ }^{450}$

A partir do art. 2 do decreto Federal n. 145 de 11 de julho de 1893, então, estando sobre a condição de não-trabalho, os indivíduos eram qualificados como vadios, viciosos e criminosos e recolhidos para ambientes disciplinadores, onde seriam incutidos hábitos de trabalho, transformando-os em mão de obra disciplinada para o mercado.

Se na época da abolição os fazendeiros buscaram utilizar o discurso da concessão da libertação dos escravos como tentativa para que o negro permanecesse nas fazendas, na República, os seus representantes tentaram se aproveitar do apoio que deram à abolição como uma forma de barganhar com o Estado. Em sessão no dia 27 de agosto de 1891, o senador José Cesario de Miranda Monteiro de

\footnotetext{
${ }^{448}$ Anais do Congresso Constituinte da República. Sessão de 16 de janeiro de 1891. Volume II, 1890, p. 507.

${ }^{449}$ Anais do Senado Federal. Sessão de 8 de outubro de 1892. Volume V. Livro 6, livro 6, p. 181.

${ }^{450}$ Anais do Senado Federal. Sessão de 8 de maio de 1893. Volume I, 1893, livro 1, p. 38.
} 
Barros, representante do estado do Espírito Santo e dos lavradores, a cuja classe pertencia, ao falar sobre o projeto de concessão de terras devolutas feita pela União e pelos estados, observa que

o Senado deve lembrar-se que esta classe mostrou o maior patriotismo na questão do elemento servil, porque sendo quase a única que era prejudicada com a solução rápida desta questão, veio ao encontro do legislador, e antes de 13 de maio muitos lavradores libertaram os seus escravos, mostrando assim que, acima de seus interesses individuais, colocavam a questão de patriotismo e caridade; (..... ${ }^{451}$

Foram também os representantes de fazendeiros que levaram para o Senado a discussão em torno da mão de obra para as lavouras, assunto de extrema relevância, como defendiam já que as lavouras estavam sofrendo com a falta de mão de obra desde 013 de maio de 1888, o que estava consequentemente afetando a produção, como proferiu o senador João Baptista Laper, proprietário rural e representante do estado do Rio de Janeiro.

Como representante do Rio de Janeiro, percorrendo o interior do estado, tenho podido observar a desgraça lastimosa a que tem chegado nossos estabelecimentos rurais, os quais pela inercia, pelo abandono, a que os entregaram os libertos, tem se visto reduzidos a quase metade das suas culturas e em certos pontos mesmo a completa desorganização. ${ }^{452}$

A preferência era pelo trabalhador europeu, visto como mais educado e possuidor de civilização mais adiantada, como ressaltava o senador e Ministro da Justiça Manoel Ferraz de Campos Salles, representante de São Paulo, Antonio Justiniano Esteves Junior, Luiz Delfino dos Santos e Raulino Julio Adolpho Horn - senadores e representantes de Santa Catarina - porém, outros deputados como Monteiro de Barros argumentavam que os europeus eram imprestáveis em zonas quentes, egoístas, não se sujeitavam e não aceitavam subordinação. Por isso, a melhor mão de obra seria a chinesa, razão pela qual o dito deputado em sessão de 31 de maio de 1892 apresentou um projeto de lei, por meio do qual criticou argumentos que defendiam que os chineses contaminariam nossa raça com seus defeitos, defendendo que somente com a vinda de imigrantes chineses para o país as lavouras seriam salvas, já que o europeu era indisciplinado e os libertos agiam com ódio e má vontade, trabalhavam de má vontade, não tinham a mesma disposição de antes e não eram leais aos lavradores. Segundo Monteiro de Barros,

da maioria dos libertos não há trabalho proveitoso a esperar, enquanto não forem educados, e este processo de educação é demorado (...). A experiência provou que o liberto tornou-se imprestável, como trabalhador, ao menos durante o longo período necessário à sua regeneração; nos países onde regam a terra com o seu suor, tem trabalhado em proveito alheio, a gente que

\footnotetext{
${ }^{451}$ Anais do Senado Federal. Sessão de 27 de agosto de 1891. Volume III. Livro 4, 1891, p. 135.

${ }^{452}$ Anais do Senado Federal. Sessão de 3 de agosto de 1892. Volume III. Livro 4, 1892, p.110.
} 
foi escrava parece ter tomado horror ao trabalho, e querer pensar que é livre mantendo-se na ociosidade. ${ }^{453}$

Além disso, Monteiro de Barros defendia que os lavradores não podiam contar com o trabalho dos libertos porque os mesmos não aceitavam ser tratados senão como iguais, faltavam muito ao trabalho e ficavam satisfeitos com os recursos provenientes de três dias de trabalho, o que levava-os a faltarem nos outros dias. Todos esses fatores estavam ligados à sua raça. Mesmo aqueles que tinham contato com hábitos de civilização, não perdiam os traços de indolência e falta de ambição, pois eram aspectos comuns à raça africana. ${ }^{454}$

O projeto de lei foi inserido na ordem dos trabalhos para ser discutido no Senado com o apoio do senador de Sergipe José Luiz Coelho e Campos; deputado Silva Paranhos, representante do Mato Grosso; o senador e primeiro secretário do Senado, representante do Piaú, Elyseu de Souza Martins; Firmino da Silveira, o senador de Alagoas Tavares Bastos, Bras Carneiro, o deputado da Paraíba João Baptista de Santos Andrade e o senador Ramiro Fortes de Barcellos, do Rio Grande do Sul. O projeto sugeria que os artigos 1 e 2 do decreto de número 528 de 28 de junho de 1890 fossem revogados. De acordo com os artigos, os "indígenas da Ásia ou da África" não eram considerados indivíduos validos e aptos para o trabalho e só poderiam ser admitidos diante de autorização do Congresso Nacional, respeitando as condições que fossem estipuladas.

Aristides da Silveira Lobo, deputado do Rio de Janeiro, ex-Ministro do Interior, por sua vez, durante as discussões do projeto de lei de n.10, posicionou-se contra a sua aprovação. Segundo ele, o clima não poderia ser razão para a imigração europeia não ser proveitosa, pois o nosso país possuía muitos climas e todos aptos aclimarem os europeus. Regiões como São Paulo, Paraná, Santa Catarina e Rio Grande obtiveram sucesso com a imigração europeia não só por conta de seu clima, mas pela iniciativa administrativa dos particulares para solucionar problemas. Ademais, deu seu próprio testemunho de

ter visto colonos italianos, no estado do Rio de Janeiro (em Valença) trabalhando lado a lado com os negros, que são incontestavelmente os nossos lavradores mais fortes e mais resistentes e nosso primeiro operário, na cultura do café, vi os italianos rivalizando com eles nas campinas, nestas que parecem mais difíceis e penosas, praticadas em terrenos íngremes ou fortemente acidentados. ${ }^{45}$

\footnotetext{
${ }^{453}$ Anais do Senado Federal. Sessão de 30 de maio de 1892. Volume I. Livro 2, 1892, p.137-38.

${ }^{454}$ Idem, p.137-157.

${ }^{455}$ Anais do Senado Federal. Sessão de 10 de agosto de 1892. Volume III. Livro 4, 1892, p.166-167.
} 
Por conseguinte, ressaltou a importância de não ser adotadas políticas efêmeras. A nação, a pátria, para Aristides Lobo, estava sendo fundada, logo, um plano de existência deveria ser seguido ao invés de leis serem aprovadas em função de um motivo ocasional. Assim, "o homem equilibrado da Europa" não deveria ser trocado pelo "enxame de aranhas humanas" que eram os chineses. Comparando a vinda de chineses com a escravidão existente no Brasil por ano, Aristides observou que

O negro que organicamente é muito superior ao chinês, que vamos importar, foi trazido ao nosso solo e submisso, sem a menor noção de sua liberdade, porque no seu próprio país ele também era escravo dos régulos que os despostiçava, 0 africano servia de maquina de trabalho e serviu para fundar fortunas individuais, não há a menor duvida. A fortuna coletiva, porém, a do Estado, a que faz a base das nações, esta desapareceu com a queda da escravidão. $E$ sabeis porque isso se deu? Porque o trabalho que não se firma, não se consorcia com a terra, não convive com ela permutando entre si as vantagens do seu amanho, o trabalho escravo, fortuito, não funda cousa alguma e serve para por em problema a sorte do operário e a daquele que o utiliza. Pois bem, é 0 que vai acontecer. ${ }^{456}$

O deputado Monteiro de Barros, por outro lado, retrucou atentando para o fato de que a lavoura foi sustentada pelo braço africano. O senador do Rio de Janeiro João Baptista Laper, por seu turno, defendeu que "o negro é superior a muitas das raças europeias quanto ao trabalho." ${ }^{57}$ Aristides, em resposta, associou a superioridade dos negros em relação aos europeus ao fato deles possuírem maior facilidade para adaptação ao trabalho porque provém de uma região com clima e solo semelhantes ao nosso. Todavia, ressaltou que sua intenção não era de comparar os europeus com os africanos, pois para ele ambos eram fortes. Seu objetivo era demonstrar que o chinês não podia ser comparado nem ao europeu nem ao africano em âmbito de força e lembrar que o chinês

leva por toda a parte onde vai, os seus hábitos, os seus costumes, as suas crenças, as suas abusões e liturgias clássicas, bem como o espetáculo de sua insensível submissão. Vindo para nós, uma de duas: ou ele é um trabalhador demasiadamente passageiro e pouco adianta, ou demora-se contagiando com as suas superstições e os seus vícios o povo brasileiro, que, como sabeis, por causas diversas, que, agora, não posso deslindar, ainda não tem o seu caráter constituído. ${ }^{458}$

Nesse sentido, a comparação feita entre a mão de obra chinesa e a mão de obra escrava estava relacionada à efemeridade de ambas. Por ser um trabalhador passageiro, como foi passageira a escravidão, não resolveria os problemas das lavouras. Aliás, a escolha do imigrante deveria ser bem pensada, já que a nação estava em processo de fundação.

\footnotetext{
456 Idem, p.168.

${ }^{457}$ Idem, p.168.

${ }^{458}$ Idem, p.168.
} 
Monteiro de Barros, em contrapartida, reconhecia que o argumento antropológico não deveria ser negligenciado. A raça caucasiana era a mais bonita, a mais adiantada em termos de civilização e de ciência, mas a raça chinesa também não podia ser qualificada como inferior, atrasada ou pouco inteligente. Por outro lado, advertia que, se uma das preocupações era com a mistura do chinês com a nossa sociedade, o fato do chinês ser passageiro não seria um fator negativo, mas positivo.

Em concordância, o senador do Rio Grande do Sul, Ramiro Fortes de Barcellos, salientou que "a introdução de elemento étnico inferior" deveria ser evitada por representar um perigo, no entanto, se não se tratasse de elemento povoador, mas apenas trabalhador não haveria problema. Por outro lado, 0 senador do Paraná Ubaldino do Amaral Fontoura ponderou que, embora a vinda de chineses para o Brasil pudesse melhorar a situação econômica das lavouras, poderia também resultar em conflitos posteriores envolvendo as raças já existentes no Brasil - a negra, a germânica, 0 branco - e 0 chinês devido à concorrência. Todavia, questionava a concepção da existência de raças inferiores e superiores.

Qual a raça superior? Qual é a raça inferior? Ainda estou por saber. O que vejo é que as raças são diferentes, que tem aptidões diversas, e que todas elas são sujeitas a esta lei (a respeito desta lei, sim, não tenho duvida), nascer, crescer e morrer. Todas as raças, como todas as coisas, veem para este destino. (...) Não conheço raça alguma imortal, como não conheço raça alguma superior. (...) Também não sei qual é a raça brasileira; a este respeito estamos em pontos muito divergentes. ${ }^{459}$

Por instrumento desse debate, podemos perceber que as teorias raciais vigentes no Império permaneciam influenciando o pensamento dos políticos na época da República. A concepção da existência de raças inferiores e raças superiores persistia. Ao longo da discussão sobre a imigração chinesa, 0 chinês era apontado como uma raça inferior. Esse posicionamento é ainda mais explícito no pronunciamento do senador Manoel Victorino, representante da Bahia, em sessão de 13 de julho de 1893, por meio do qual destacou a necessidade de se colocar em prática a medida adotada no ano anterior referente à introdução de imigrantes chineses nas lavouras do país. Para o senador, o chinês não representava uma ameaça, pois

ele não pode fazer-nos mal, porque seria preciso que as raças fracas influíssem sobre as mais perfeitas. 0 chim não se imiscuirá na nossa políica, como os italianos já o estão fazendo; só virão como meros auxiliares ou trabalhadores, dóceis, inofensivos. (...) a immigração chinesa será o recurso único de que podemos lançar mão para vencer a transição entre o braço escravo e 0 elemento mais pacífico da civilização americana. ${ }^{460}$

\footnotetext{
${ }^{459}$ Idem, p.162.

${ }^{460}$ Anais do Senado Federal. Sessão de 13 de julho de 1893. Volume II, 1893, p. 277.
} 
Dois dias depois, Joaquim de Oliveira Catunda, representante do Ceará, ressaltou que o chinês sujeitava-se a qualquer situação e se satisfazia na animalidade. Diante da proposição do senador do Piauí e Primeiro Secretário do Senado Elyseu Martins - que afirmava não termos trabalhadores suficientes, 0 que levava a necessidade de recorrer à mão de obra chinesa - observou:

a raça é fraca, é imbele: satisfaçam-lhe animalidade e ela se sujeitará a tudo. 0 resultado é este: emancipamos o braço africano; havemos de ter a escravidão amarela, o braço mongólico. ${ }^{461}$

O preconceito racial, portanto, era vivo na mentalidade da elite política da época e acabavam por se refletir ao longo dos debates no Senado, de modo que a questão racial era usada inclusive para justificar erros políticos. Em sessão de 26 de junho de 1891, o senador Campos Salles, colocou-se contra um ato oficial. Segundo o mesmo, o Senado havia recebido no dia anterior uma mensagem do executivo com a informação de que os documentos referentes ao tratado das Missões - cuja requisição havia sido deliberada dia 22 - não tinham sido entregues ao Senado porque os mesmos já tinham sido enviados à Câmara dos Deputados, o que aparentemente não fazia sentido porque somente no dia 25 os papeis foram levados à Câmara. Para o senador, tal atitude poderia ter causado um entrevero entre a Câmara e 0 Senado, que mantinham uma relação harmônica. Nesse sentido, comparando o governo presidencial brasileiro com o norte americano, observou que os atos do executivo deveriam ser um complemento dos preceitos constitucionais. Enquanto Campos Salles fazia sua explanação, um senador, cujo nome não é citado, observou que "isso é questão de raça". O Ministro da Justiça, porém, posicionou-se contra a afirmação do companheiro, ponderando que os percursos tomados na política do Brasil não deveriam ser associados à raça.

Não; não é questão de raça. É um erro atribuir os nossos defeitos políticos à nossa raça. (...) A diferença entre nós e os americanos do norte consiste em que lá, no período da iniciação do novo regime, predominou o sentimento do patriotismo, que erguia os espíritos superiores ás grandes alturas, de onde não se veem senão os destinos da pátria, de onde não se podem avistar os interesses egoísticos que geram-se à sombra dos sentimentos pessoais, e que, quanto mais se agrupam em torno da individualidade investida do poder público, mas isolam da pátria. ${ }^{462}$

O aspecto racial foi também lembrado como fator para que o recrutamento militar não fosse realizado por meio de sorteio. Em sessão de 16 de janeiro de 1891, o deputado João da Silva Retumba,

\footnotetext{
${ }^{461}$ Idem. Sessão de 15 de julho de 1893, p. 283.

${ }^{462}$ Anais do Congresso Constituinte da República. Sessão de 27 de junho de 1891. Volume I. Livro 3, p. 145.
} 
representante da Paraíba e oficial da marinha, protestou contra o artigo 83 da Constituição, por meio do qual seria abolido o recrutamento militar obrigatório e estabelecido o sorteio, mediante prévio alistamento, para compor o Exército e a Armada, alegando que em um país heterogêneo o sorteio seria um erro, pois não se podia contar com o patriotismo do povo.

Senhores, em um pais como o Brasil, onde seu povo é completamente heterogêneo, onde não há educação nacional, onde somente se conta um decimo da população que sabe ler e escrever população ainda - composta de diversas raças, oriundas do índio bravio, porém selvagem, oriunda do preto africano imbecil e indolente, oriunda de nossos primeiros colonos, os portugueses, em sua maior parte gales! Como em tão pouco tempo se quer a homogeneidade da nossa sociedade? Como se quer estabelecer um sorteio militar; para que de entre o povo saiam, espontaneamente servidores para a pátria? Pois, senhores do Congresso, não conheceis a ojeriza do povo brasileiro pelo serviço militar, pela responsabilidade do mando, pela dificuldade e rigor do trabalho? $?^{463}$

Associando a falta de patriotismo a presença de diferentes raças no Brasil, Retumba afirma não ser contra a ideia do voluntariado, mas enquanto as raças não tivessem se apurado, enquanto o país não alcançasse o homogeneidade, o serviço militar não poderia ser realizado por meio de sorteio. Buscando 0 apoio dos demais membros do Senado, questionou:

Permitam agora os senhores do Congresso que eu vos faça uma pergunta: se um de vossos filhos for sorteado, consentireis de bom grado que ele, criado no seio da família e tendo uma educação a mais pura e a mais apta, vá meter-se em um quartel e conviver com homens de raça e educação diferente e desigual? ${ }^{464}$

As reformas políticas e sociais, como podemos observar, eram evitadas pela elite política do Brasil. Essa dificuldade, porém, para alguns deputados, não deveria ser um obstáculo para que as mesmas não fossem implementadas, pois, se para que as reformas fossem implementadas, tivesse que haver concordância por parte da sociedade, viveríamos em completo estado estacionário. Nesse âmbito, 0 deputado José Vicente Meira de Vasconcellos, representante de Pernambuco, ao defender o federalismo, influenciado pela Constituição dos Estados Unidos, comparou a vida coletiva da sociedade ao organismo humano, observando que até que a sociedade alcance a civilização, ela passa por momentos incertos, sofrimentos e sacrifícios.

Se quisermos esperar o preparo dos povos para a adaptação das reformas sociais e si quisermos admitir que sem esse preparo elas não devem ter lugar, teremos negado toda a liberdade ao

\footnotetext{
${ }^{463}$ Anais do Congresso Constituinte da República. Sessão de 16 de janeiro de 1891. Volume II. Livro 1, p. 332.

${ }^{464}$ Idem, p. 333.
} 
povo, teremos proclamado o estacionarismo chinês. Se assim fosse, nós ainda hoje seriamos um pais de escravos; não teríamos esta brilhante conquista da extinção da escravidão em nossa pátria.(...) Vós bem sabeis que os primeiros que tiveram a ousadia e a coragem patriótica de dizer ao seu pais e ao mundo que o Brasil precisava lavar da face da sua civilização aquela nodoa que o tornava quase repugnante ao mundo civilizado, foram cobertos de approbios, de doestos, de maldição. ${ }^{465}$

De maneira semelhante, o senador Ubaldino do Amaral, ao defender a questão operária, fez um alerta sobre o posicionamento do poder público diante de pretensões sociais.

toda a vez que há uma pretensão social em jogo, os poderes públicos limitam-se a abster-se de tomar conhecimento dela, em vez de se associarem, isto é, tomarem conhecimento dela, medindo-lhe a sua legitimidade, a sua razão de ser, mostram-se na maioria dos casos resistentes ou indiferentes; e, somente quando a pretensão de caráter social toma proporções assustadoras, cobre-se de asperezas difíceis, é que os poderes públicos interveem e procuram tomar medidas que no momento nem sempre são as melhores. (...) Foi isto mesmo que viu-se na própria abolição. ${ }^{466}$

O possível envolvimento de libertos na politica causava desconforto, pois os ex-escravos eram identificados como despreparados, pois não tinham educação, não eram conscientes, disciplinados e higienizados. Ainda que com a abolição da escravidão, o negro tenha passado a ser um novo elemento a ser considerado, o discurso defendido pelo Estado republicano privilegiava uma totalidade, sem valorizar as diferenças internas, visto que a mentalidade da recém extinta sociedade escravista persistia de forma que os republicanos permaneciam atrelados a heranças imperiais o que distanciou o envolvimento popular na implantação do novo regime, bem como na delimitação da construção da imagem nacional.

Em 1894, Nina Rodrigues, jovem médico mulato, catedrático da faculdade da Bahia, responsável pelo primeiro estudo etnográfico sobre os afro-brasileiros feito por um brasileiro, publicou a obra As raças humanas e a responsabilidade penal no Brasil, por meio da qual recomendava que a responsabilidade penal de índios e negros fosse inferior a dos brancos, pois se tratavam de raças inferiores, marcadas pela "impulsividade primitiva, fonte e origem de atos violentos e antissociais" e dessa forma seus crimes estavam ligados a "insuficiência da consciência do direito do dever". ${ }^{467}$

Assim, os indivíduos permaneciam sendo julgados conforme a cor. A hierarquia racial, como no Império, foi conservada, mas a suposta diferença entre as raças não continuou a dar brechas para

\footnotetext{
${ }^{465}$ Anais do Congresso Constituinte da República. Sessão de 12 de janeiro de 1891. Volume II, 1890, p. 388-389.

${ }^{466}$ Anais do Senado Federal. Sessão de 21 de junho de 1893. Volume II, 1893, p. 67.

${ }^{467}$ RODRIGUES, Nina. "As raças humanas nos códigos penais brasileiros.", in: As raças humanas e a responsabilidade penal no Brasil. Com um estudo do professor Afranio Peixoto. Ed. Guanabara, 1995, p. 69-88. Disponível em www.cairu.br/biblioteca/arquivos/Direito/As_racas_humanas_responsabilidade_penal_Brasil.pdf. Acesso em 06 de março de 2014.
} 
discursos que associavam a nossa mestiçagem a uma visão pessimista em relação ao futuro. Ao que tudo indicava, a proposta do médico sergipano Silvio Romero parecia estar sendo colocada em prática, pelo menos no âmbito político - apesar de compreender o mestiço como racialmente inferior, defendia que não adiantava discutir se a mestiçagem era boa ou ruim, era preciso pensar soluções para garantir o progresso do país. ${ }^{468}$

Nesse sentido, a vinda de "raças inferiores" como os chineses era temida por alguns, a imigração dos europeus e consequentemente o possível branqueamento era apoiado pela maioria, mas a mistura das três raças não era mais comumente retratada como fator de impossibilidade de progresso e de civilização. Cabia procurar garantir a transformação do Brasil em um país civilizado. Com esse fim, a participação politica foi restrita a um pequeno grupo, a maior parte do povo foi mantida afastada da arena politica, a tensão em torno da cor permanecia, o preconceito de cor disfarçava-se em meio aos debates, os proprietários rurais se preocupavam apenas com a lavoura, a mão de obra imigrante, principalmente europeia, era preferida em detrimento da mão de obra negra e, por fim, o Estado mantinha-se distante da população.

Assim, embora a virada do século XIX para o século XX tenha sido marcada por rupturas significativas graças ao fim da escravidão e à Proclamação da República, o que aparentava representar uma possibilidade de mudança no panorama político e social da época, revelou-se como uma impossibilidade. A lei Áurea instituiu a abolição, mas não eliminou as marcas da escravidão do país. A igualdade, a cidadania e a inclusão dos ex-escravos não foram determinadas pela lei assinada pela princesa Isabel tampouco foram pela recém-República.

\section{REFERÊNCIAS}

\section{FONTES}

Anais do Congresso Constituinte da República. Anos:

1890 - 4 livros

1891 - 7 livros

1892 - 6 livros

$1893-4$ livros

1894 - 6 livros

Diário de Notícias, 15 de maio de 1888.

${ }^{468}$ DANTAS, Carolina Vianna. "O Brasil café com leite: debates intelectuais sobre mestiçagem e preconceito de cor na primeira república". Tempo [online]. 2009, vol.13, n.26, pp. 56-79. 
Gazeta de Notícias. 01 de janeiro de 1893.

Gazeta de Notícias, 14 de maio de 1893.

Jornal do Senado, 14 de maio de 1888.

O Paiz, 8 de maio de 1890.

BRASIL. Decreto n 8213, de 13 de agosto de 1881. Regula a execução da Lei no 3029 de 9 de janeiro do corrente ano que reformou a legislação eleitoral. Coleção das Leis do Império do Brasil. Rio de Janeiro, v. 2.

Falas do Trono. Desde o ano de 1823 até o ano de 1889. Prefácio de Pedro Calmon. Brasília: INL, 1977.

\section{REFERÊNCIAS BIBLIOGRÁFICAS}

ALBUQUERQUE, Wlamyra R. de. O jogo da dissimulação - abolição e cidadania negra no Brasil. São Paulo: Companhia das Letras, 2009.

CARVALHO, José Murilo de. Cidadania no Brasil. O longo caminho. Rio de Janeiro: Civilização Brasileira, 2013.

CHAULHOUB, Sidney. Machado de Assis historiador. SP: Companhia das Letras, 2003. CHALHOUB, Sidney. "Medo Branco de Almas Negras: Escravos, Libertos e Republicanos na Cidade do Rio". IN: (Revista Brasileira de História - São Paulo, ANPUH/Marco Zero, vol. 8, n 16, março de 1988 / agosto de 1988.

CUNHA, Olívia Maria Gomes da; GOMES, Flávio dos Santos (orgs.). Quase-cidadão: histórias e antropologias da pós-abolição. Rio de Janeiro: FGV, 2007.

DANTAS, Carolina Vianna. "O Brasil café com leite: debates intelectuais sobre mestiçagem e preconceito de cor na primeira república". Tempo [online]. 2009, vol.13, n.26, pp. 56-79.

FRANCO, Álvaro da Costa. (org.) Com a palavra, o Visconde do Rio Branco. A politica exterior no Parlamento Imperial. Rio de Janeiro: CHDD/FUNAG, 2005.

FREIRE, Gilberto. Casa-Grande \& Senzala. Formação da Família Brasileira sob o Regime da Economia Patriarcal. São Paulo: Ed. Global, 2006.

GOMES, Heloísa Toller. As Marcas da Escravidão. Rio de Janeiro: EDUERJ, 1994.

LACOMBE, Américo Jacobina; SILVA; Eduardo Silva e BARBOSA, Francisco de Assis. Rui Barbosa e a Queima dos Arquivos. Brasília: Ministério da Justiça; Rio de Janeiro: Fundação Casa de Rui Barbosa, 1988.

LARA, Sílvia Hunold. Escravidão, cidadania e história do trabalho no Brasil. Revista projeto História, São Paulo, vol. 16, fevereiro-1998.

MATTOS, Hebe Maria. "Racialização e cidadania no Império do Brasil", In: CARVALHO, José Murilo de; BASTOS, Lúcia Maria (orgs.). Repensando o Brasil dos oitocentos. Rio de Janeiro: Civilização Brasileira, 2009.

MATTOS, Hebe Maria. \& RIOS, Ana Maria. "Para além das senzalas: campesinato, politica e trabalho rural no Rio de Janeiro pós-abolição", in: CUNHA, Olívia Maria Gomes da \& GOMES, Flávio dos Santos. (orgs.). Quase-cidadão: histórias e antropologias da pós-abolição. Rio de Janeiro: FGV, 2007.

PINSKY, Jaime. \& PINSKY, Carla Bassanezi. (orgs.) História da cidadania. São Paulo: Ed. Contexto, 2013. RODRIGUES, Nina. "As raças humanas nos códigos penais brasileiros.", in: As raças humanas e a responsabilidade penal no Brasil. Com um estudo do professor Afranio Peixoto. Ed. Guanabara, 1995.

SKIDMORE, Thomas E. Preto no Branco. Raça e nacionalidade no pensamento brasileiro. (1970-1930) SP: Companhia das Letras, 2012. 
SCHWARCZ, Lilia Moritz. "Dos males da dádiva: sobre as ambiguidades no processo da Abolição brasileira", in: CUNHA, Olívia Maria Gomes da \& GOMES, Flávio dos Santos. (orgs.). Quase-cidadão: histórias e antropologias da pós-abolição. Rio de Janeiro: FGV, 2007.

SCHWARCZ, Lilia Moritz. O espetáculo das raças. Cientistas, instituições e questão racial no Brasil (18701930). São Paulo: Companhia das Letras, 2011.

SCHWARCZ, Lilia Moritz. População e sociedade, in: SCHWARCZ, Lilia Moritz. (org.) A Abertura para o mundo. 1889-1930. Volume 3 da Coleção: História do Brasil nação: 1808-2010. RJ: Editora Objetiva, 2012. 